\title{
FUEL INJECTION TIMINGS OF A DIRECT INJECTION DIESEL ENGINE RUNNING ON NEAT LEMONGRASS OIL-DIESEL BLENDS
}

\author{
Sathiyamoorthi R. ${ }^{{ }^{*}}$ and Sankaranarayanan G. ${ }^{2}$ \\ ${ }^{1}$ Research Scholar, Department of Mechanical Engineering, \\ Anna University, Chennai, Tamilnadu, India \\ *Email: sathiya.ram78@gmail.com \\ Phone: +919789228456; \\ ${ }^{2}$ Department of Mechanical Engineering, \\ Sree Sastha Institute of Engineering \& Technology, \\ Chennai, Tamilnadu, India \\ Email: gs2000narayanan@gmail.com
}

\begin{abstract}
In this study, the effect of neat lemongrass oil [1]-diesel blends on the performance, combustion and emission characteristics of a direct injection diesel engine was investigated with different injection timings of $21^{\circ}$ (retarded), $23^{\circ}$ (normal) and $27^{\circ}$ (advanced) bTDC positions by using four different fuel blends of diesel, LGO25, LGO50 and neat lemongrass oil. The experimental results show that maximum cylinder pressure and heat release rate increased with advanced fuel injection timing for all test fuels. There was a reduction in BSFC and significant improvement in the brake thermal efficiency (BTE) with advanced injection timing. Emissions from the diesel engine such as smoke and hydrocarbon ( $\mathrm{HC}$ ) were reduced but $\mathrm{NO}_{\mathrm{X}}$ emission was very high with advanced injection timing compared with other injection timings. When the injection timing is advanced, ignition delay increases, which leads to the more prominent initial phase of combustion in the premixed region. In the light of the experimental results, the optimal injection timing determined for LGO-diesel blends was found to be $27^{\circ}$ bTDC.
\end{abstract}

Keywords: Performance; emission; lemongrass oil; combustion.

\section{INTRODUCTION}

Research has intensified on identifying greener alternative fuel substitutes for diesel engines. Compression ignition engines are widely used for agricultural, automotive, transportation and industrial sectors because of their better fuel economy and higher thermal efficiency $[2,3]$. Because of increasing concern about environmental issues and more stringent government regulations, many researchers have focused on the reduction of exhaust emission levels and improving fuel economy of internal combustion (IC) engines [2, 4-7]. A lot of research related to engine emission reduction and higher performance has used three important engine parameters: different injection pressure, injection timing and compression ratio [8-12]. The fuel injection timing is an important parameter that affects combustion and emissions [3, 13]. When the start of injection timing is advanced, the initial air temperature and pressure are lower, leading to an increase in ignition delay. The increase in ignition delay periods is the reason for the 
higher cylinder gas temperature and $\mathrm{NO}_{\mathrm{x}}$ emissions [13]. When the start of fuel injection timing is retarded, the temperature and pressure are slightly higher so that the ignition delay period decreases $[14,15]$. Therefore, the variation in injection timing exhibits a solid effect on the combustion and exhaust emissions. The other methods use oxygenated fuels, exhaust gas recirculation (EGR), thermal barrier coatings (TBC), and combustion chamber geometry for emission reduction and better performance. Various investigators have reported that injection parameters have an effect on engine performance and exhaust emissions. Various experimental studies conducted by Rahman et al. [16] with an advancement in injection timing using biodiesel, alcohol and other alternative fuels and found that lower carbon monoxide $(\mathrm{CO})$ and hydrocarbon (HC) emission but an increase in nitrogen oxide $\left(\mathrm{NO}_{\mathrm{x}}\right)$ emission. Further, they observed that advanced injection timing increases brake thermal efficiency (BTE) and decreases brake specific fuel consumption (BSFC). Another researcher studied [17] the effects of injection pressure and injection timing in a single-cylinder CRDI diesel engine fueled with waste cooking oil (WCO) biodiesel and commercial diesel fuel. The engine tests were conducted at injection pressure of 80 and $160 \mathrm{MPa}$ and different injection timings from -25 to 0 crank angle degree (CAD) after TDC. The author observed an increase in specific fuel consumption, lower peak cylinder pressure and peak heat release rate, slightly longer ignition delay, and reduction in smoke, $\mathrm{CO}$, and $\mathrm{HC}$ emissions but an increase in $\mathrm{NO}_{\mathrm{x}}$ emission.

The effect of injection timing on $\mathrm{NO}_{\mathrm{x}}$ emission by a biodiesel blend was investigated theoretically and experimentally [18] with fuel injection timing retardation. It was observed that lower $\mathrm{NO}_{\mathrm{x}}$ emission was accompanied by an increase in smoke. Experimental studies were conducted by Junheng et al. [19] on a six-cylinder turbocharged intercooled heavy duty (HD) diesel engine in diesel/methanol compound combustion mode (DMCC). It was observed that peak cylinder pressure and heat release rates increased during the advanced injection timing and BSEC and exhaust gas temperature of DMCC engine decreased. $\mathrm{NO}_{\mathrm{x}}$ increased and soot decreased as the diesel injection timings were advanced. In addition, the $\mathrm{HC}$ and $\mathrm{CO}$ emissions in DMCC mode exhibited a decreasing trend in proportion to an advance in the injection timing. Another effective method was tried [20] with the port premixing of DME; also the heat release process comprised premixed homogeneous charge compression ignition combustion and diffusion combustion. At a fixed DME quantity, BSFC was lowest when diesel was injected into a cylinder at $7^{\circ}$ bTDC. Further, as more DME was aspirated from port, $\mathrm{NO}_{\mathrm{x}}$ emissions decreased but later this showed decreasing trends. Smoke reduced, but $\mathrm{CO}$ and $\mathrm{HC}$ increased with a rise in DME quantity. During the direct injection diesel engine operation, $\mathrm{NO}_{\mathrm{x}}$ increased but smoke, $\mathrm{CO}$ and $\mathrm{HC}$ decreased with an early direct injection. Some researchers [3, 21, 22] investigated the combined effect of advanced injection timing and various injection pressures and found that BMEP and BTE increased, while BSFC and exhaust gas temperature reduced significantly. $\mathrm{CO}$ and $\mathrm{HC}$ emissions were reduced but $\mathrm{NO}_{\mathrm{x}}$ emissions were increased with advanced injection timings.

Experimental studies have been conducted by Ryu et al. [13] using a dual fuel (biodiesel and $\mathrm{CNG}$ ) with pilot injection pressure of $120 \mathrm{MPa}$ and injection timing of $11-23^{\circ}$ bTDC. It was observed that BSEC of biodiesel-CNG is improved with advanced pilot injection timing at low loads and with delayed pilot injection timing at full loads. Smoke is decreased and $\mathrm{NO}_{\mathrm{x}}$ is increased with advanced pilot injection timing. Further, SFC and smoke are significantly reduced. However, a direct injection (DI) diesel engine was tested with different combustion chamber geometry and different injection timings 
[23] with $20 \%$ Pongamia oil methyl ester [24] and pistons with hemispherical and toroidal re-entrant combustion chamber (TRCC) geometries. The test results showed an improvement of 5.64\% in BTE, a reduction of $4.6 \%$ in BSFC and an $11 \%$ increase in the $\mathrm{NO}_{\mathrm{x}}$ level. An HCCI engine was used by Kim [25] with a narrow spray angle and advanced injection of $80^{\circ}$ bTDC to $10^{\circ}$ bTDC using a dimethyl ether [26] fueled diesel engine. The bowl shape of the piston head was modified to apply the narrow spray angle and advanced injection timing. It was found that $\mathrm{NO}_{\mathrm{x}}$ emissions at injection timing of $30^{\circ}$ bTDC decreased, while $\mathrm{HC}$ and $\mathrm{CO}$ emissions at injection timing of $70^{\circ} \mathrm{bTDC}$ increased. $\mathrm{NO}_{\mathrm{x}}$ emission was analyzed by Buyukkaya et al. [27] with variation of injection timing in a low heat rejection turbocharged direct injection diesel engine. For the original injection timing of the $20^{\circ}$ bTDC, the BSFC of the engine was approximately $6 \%$ lower than the original engine. $\mathrm{NO}_{\mathrm{x}}$ emissions were also higher than those of the original engine. To reduce $\mathrm{NO}_{\mathrm{x}}$ emissions released by the diesel engines, the injection timing retard was set as $18^{\circ}$ and $16^{\circ} \mathrm{bTDC}$. The results showed that BSFC and $\mathrm{NO}_{\mathrm{x}}$ emission were reduced by $2 \%$ and $11 \%$ respectively by retarding the injection timing. The literature review shows that combustion and emission characteristics are influenced by injection timings. The other parameters such as fuel injection rate, fuel nozzle design and fuel injection pressure all affect the characteristics of the diesel fuel spray and its mixing with air in the combustion chamber. The present study aims to investigate the performance, emission and combustion characteristics of a singlecylinder diesel engine running on neat lemongrass oil-diesel blends with various injection timings of $21^{\circ}, 23^{\circ}$ and $27^{\circ}$ bTDC.

\section{METHODS AND MATERIALS}

Lemongrass (Cymbopogan citratus) is a member of the grass family that contains 1 to $2 \%$ essential oil on a dry basis. Lemongrass oil has a lemony, sweet smell and is dark yellow to amber and reddish in color, with a watery viscosity. The main component of lemongrass oil is Cymbopogon citral, or citral. Lemongrass oil consists of 65 to 85 percent citral. Citral is a pale yellow liquid, often colorless, with a strong fresh lemon smell. It is extracted from fresh leaves by steam distillation. The calorific value of neat lemongrass oil is $83.6 \%$ of standard diesel fuel.

Table 1. Properties of neat lemongrass oil-diesel blends.

\begin{tabular}{lllll}
\hline \multicolumn{1}{c}{ Properties } & Diesel & LGO25 & LGO50 & Neat LGO \\
\hline Gross calorific value $(\mathrm{MJ} / \mathrm{kg})$ & 43.35 & 41.69 & 39.88 & 36.279 \\
Kinematic viscosity $(\mathrm{Cst})$ at $40^{\circ} \mathrm{C}$ & 3.25 & 3.48 & 3.71 & 4.18 \\
Specific gravity $(\mathrm{g} / \mathrm{cc})$ at $27^{\circ} \mathrm{C}$ & 0.84 & 0.876 & 0.912 & 0.984 \\
Flash point ${ }^{\circ} \mathrm{C}$ & 55 & 53.5 & 52.5 & 50 \\
Cetane index & 48 & 45.5 & 43 & 38 \\
\hline
\end{tabular}

The standard diesel fuel was purchased from the Indian Oil Corporation Petrol Bunk. Neat lemongrass oil was obtained from local commercial oil suppliers. Fuel specifications of the neat lemongrass oil were determined by the chemical laboratory. In this study, four fuels were prepared and the main properties of LGO-diesel fuels and the volumetric percentage of fuel blends are provided in Table 1 and Table 2. 
Table 2. Volumetric percentage of fuel used.

\begin{tabular}{ll}
\hline Abbreviation & \multicolumn{1}{c}{ Percentage of fuel } \\
\hline D00 & $100 \%$ diesel \\
LGO100 & $100 \%$ neat lemongrass oil \\
LGO25 & $75 \%$ diesel $+25 \%$ neat lemongrass oil \\
LGO50 & $50 \%$ diesel $+50 \%$ neat lemongrass oil \\
\hline
\end{tabular}

\section{Experimental Procedure}

The experiments were conducted on a four-stroke, naturally aspirated, single-cylinder direct injection diesel engine. The experimental setup is shown in Figure 1. Fuel consumption was quantified by measuring $10 \mathrm{~cm}^{3}$ of diesel and neat LGO separately in a burette. An electrical dynamometer (Powerstars) was directly coupled to the engine output shaft. $\mathrm{CO}, \mathrm{CO}_{2}, \mathrm{HC}$ emissions were measured by a five-gas analyzer (AVL Digas 444). Smoke was measured by an AVL 437C smoke meter and a chromyl alumel (k-type) thermocouple was used to measure the exhaust gas temperature. The specification and accuracy of the gas analyzer and smoke meter are given in Table 3. The specifications of the engine are shown in Table 4 . The experiments were carried out at three different injection timings of $21^{\circ}, 23^{\circ}$, and $27^{\circ}$ bTDC with optimum injection pressure of $200 \mathrm{bar}$ at a constant speed of $1500 \mathrm{rpm}$. The main elements of the experimental setup were the two fuel tanks (diesel and neat LGO), exhaust gas line, data acquisition system, smoke measurement, computer, electrical loading device and fivegas analyzer. To ascertain the accuracy of the measured values, the gas analyzer was calibrated before each measurement by using reference gases. The smoke meter was also calibrated to adjust its zero point before each measurement. All the tests were conducted from no load to full load. The injection timing was varied by changing the number of shims. The standard engine was fitted with three shims for standard injection timing of $23^{\circ}$ bTDC. The injection timings were varied for $21^{\circ}$ and $27^{\circ}$ bTDC by changing the number of shims. The engine was started with diesel and once it had warmed up readings were taken for each load. The experiments were carried out with five test fuels at different engine operating conditions and the engine was allowed to run long enough to consume the remaining fuel from the previous test before running with new fuel. Thus, different injection timings were analyzed and the performance, combustion and emission characteristics of neat lemongrass oil were compared with those of standard diesel fuel blends by the graphical method.

Table 3. Specification of gas analyzer and smoke meter.

\begin{tabular}{cccc}
\hline \multicolumn{4}{c}{ Specification of AVL Digas 444 } \\
\hline Emission gas & Range & Accuracy & $\%$ Error \\
$\mathrm{NO}_{\mathrm{x}}$ & $0-5000 \mathrm{ppm}$ & $+10 \mathrm{ppm}$ & $\pm 1 \mathrm{ppm}$ \\
$\mathrm{CO}$ & $0-10$ vol. $\%$ & 0.01 & $\pm 0.01 \%$ \\
$\mathrm{HC}$ & $0-20000 \mathrm{ppm}$ & $+10 \mathrm{ppm}$ & $\pm 1 \mathrm{ppm}$ \\
\hline \multicolumn{4}{c}{ Specification of smoke meter } \\
\hline
\end{tabular}




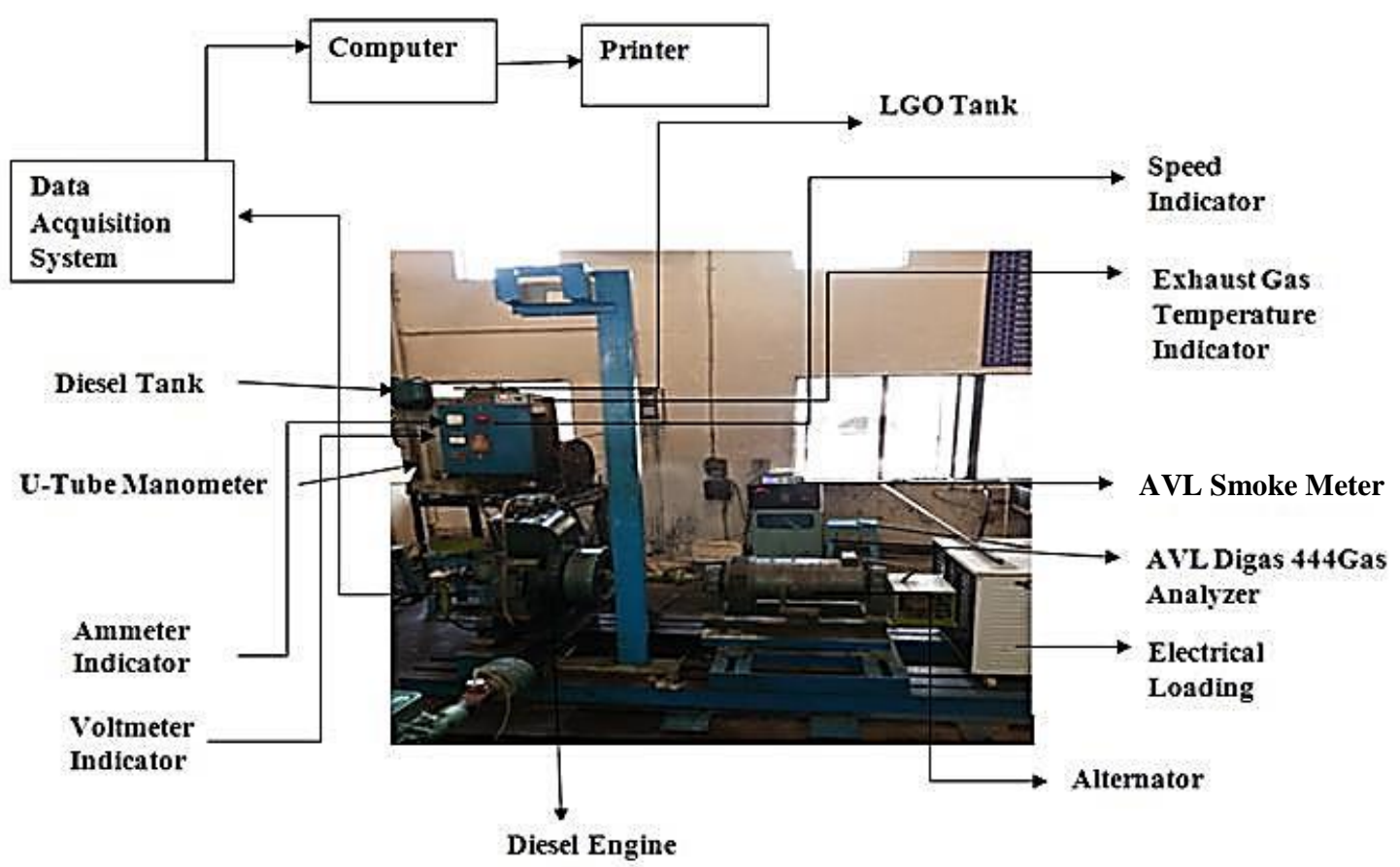

Figure 1. Experimental setup.

Table 4. Test engine specifications.

\begin{tabular}{ll}
\hline Specification & Description \\
\hline Model & Kirloskar TAF 1 \\
Type & Single-cylinder, 4-stroke, direct injection \\
Power & $4.4 \mathrm{~kW}$ \\
Bore and stroke & $87.5 \mathrm{~mm} \& 110 \mathrm{~mm}$ \\
Compression ratio & $17.5: 1$ \\
Rated speed & $1500 \mathrm{rpm}$ \\
Cooling type & Air cooling \\
Fuel injection pressure & 200 bar \\
\hline
\end{tabular}

For each fuel, the combustion characteristics and exhaust emission readings were processed and stored in a personal computer for further processing of results. For every operating condition, 50 engine pressure cycles were recorded, and the mean cylinder pressure was calculated. The mean cylinder pressure diagram and data collected from the DDA (digital data acquisition) were used to estimate the heat release and the cylinder pressure rates to find the combustion characteristics by the graphical method. After completion of the tests with neat LGO, the engine was switched back to diesel before being stopped. This prevented deposits and cold starting problems caused by the purging of neat LGO in the fuel line, injection pump and injector. 


\section{RESULTS AND DISCUSSION}

\section{Performance Characteristics}

Figure 2 shows the variation in BSFC of LGO-diesel blends for different fuel injection timings. At low load conditions, BSFC values increase at higher loads. With advanced injection timing, BSFC decreases compared with other fuel injection timings for all the LGO-diesel blends. This is mainly caused by combustion when the injection timing is advanced. Further, the results revealed an increase in cylinder pressure when the cylinder volume expanded rapidly. As a result, lower BSFC was observed [28]. BSFC increased by $4 \%$ at normal injection and nearly the same at retarded injection timing for pure diesel; BSFC was also higher by $20 \%$ at normal injection and $8 \%$ at retarded injection timings for LGO25, by $8 \%$ at normal and $12 \%$ at retarded for LGO50 and by $4.1 \%$ at retarded and $20.8 \%$ at normal injection timings compared with advanced injection timing. The decrease in BSFC at advanced fuel injection timing may be the result of a change in the combustion timing caused by the cetane number of neat LGO and also the advanced injection timing changes [29].
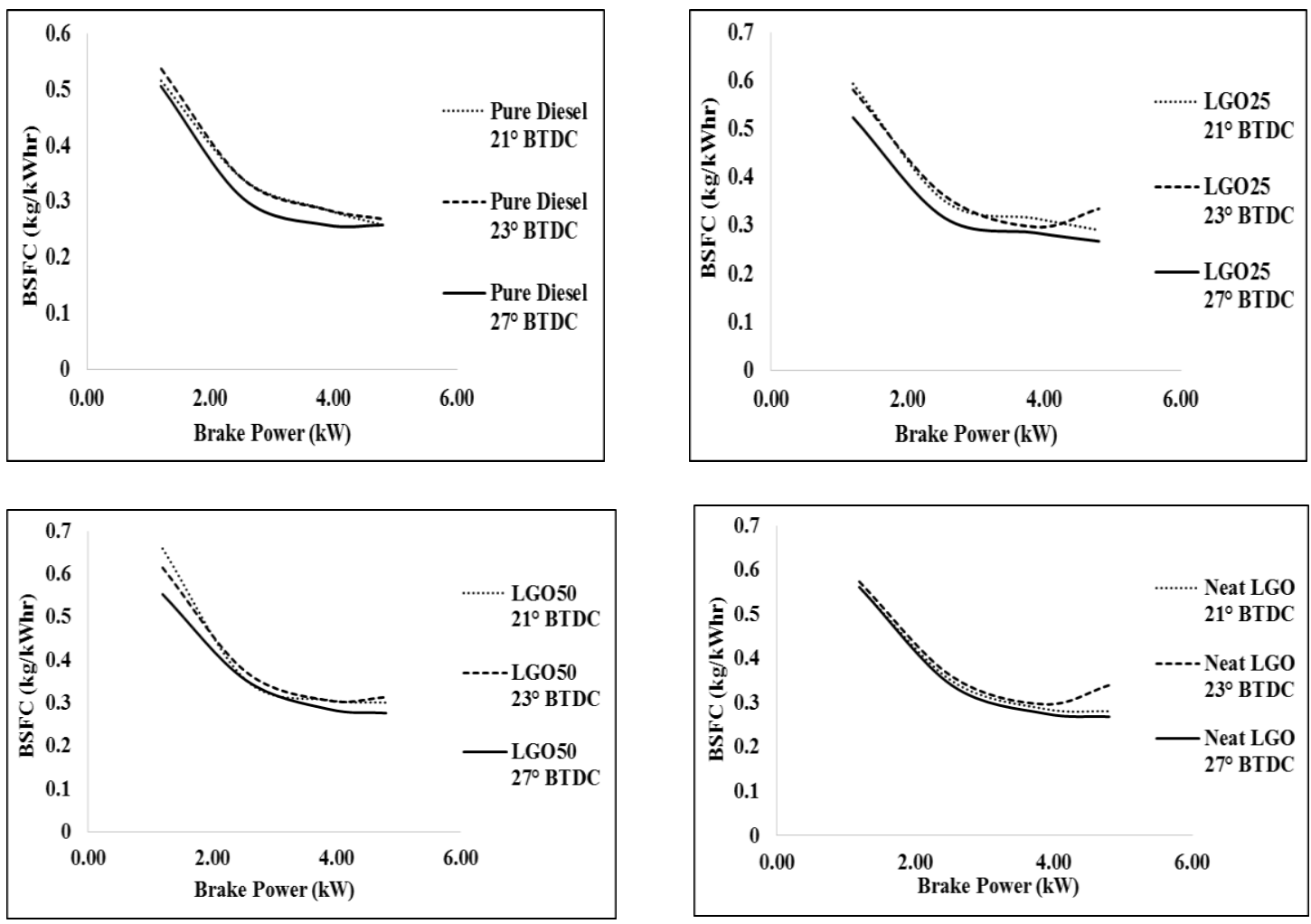

Figure 2. Variation of BSFC with brake power of LGO-diesel blends for different injection timings.

Figure 3 shows the variation of brake thermal efficiency of LGO-diesel blends for different injection timings. BTE shows an increasing trend at advanced injection timing compared with other injection timings. At the advanced injection timing, BTE is increased by $4 \%$ more than the normal injection timing for pure diesel fuel operation. 
The reason may be the accumulation of a large quantity of evaporated fuel in the combustion chamber during the ignition delay period; it burns quickly, which leads to a rapid heat release rate and causes a sudden increase in temperature and pressure in the cylinder. Thus, the BTE may increase[3]. Moreover, BTE increases by $8 \%$ and $20 \%$ for LGO25 and $4.1 \%$ and $20.8 \%$ for neat LGO compared with the retarded and normal fuel injection timings respectively. The reason may be the complete combustion caused by the finer atomization of fuel and the high lubricity of the neat lemongrass oil compared with diesel fuel $[28,30]$
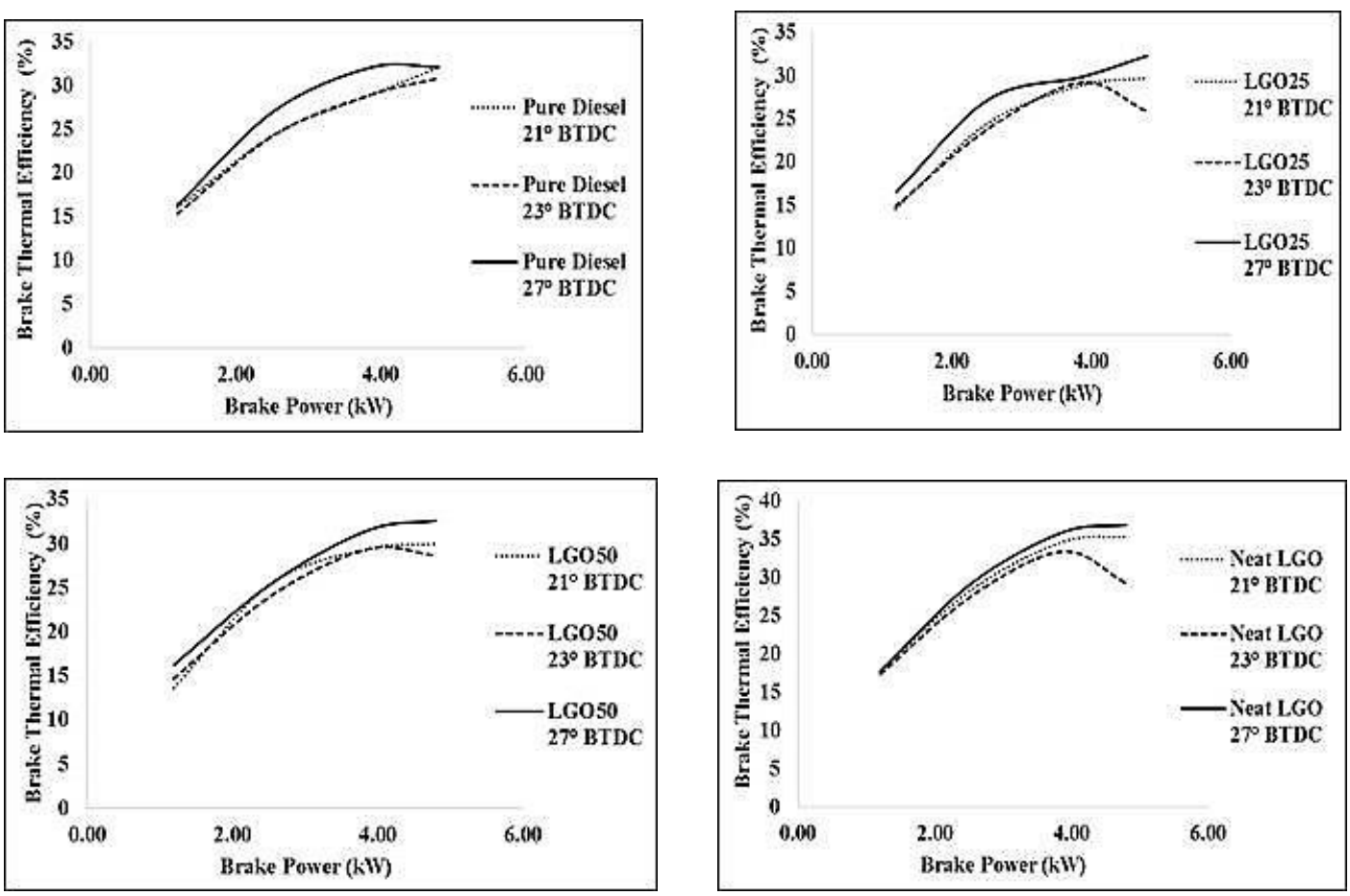

Figure 3. Variation of BTE with brake power of LGO-diesel blends for different injection timings.

\section{Combustion Characteristics}

Combustion in diesel engines is a complex heterogeneous process. Mixture formation and combustion are controlled by interactions between several parameters such as injection spray, air motion and combustion chamber geometry. Mixture formation and combustion are highly dependent on fuel injection parameters. Precise control of fuel injection,, spray formation and fuel atomization is essential for controlling combustion. Figure 4 shows the variation in cylinder pressure with various crank angles of LGOdiesel blends for different injection timings of $23^{\circ}, 21^{\circ}$ and $27^{\circ}$ bTDC. The ignition delay is the period between the start of fuel injection into the combustion chamber and the start of combustion. Ignition delay is increased at the advanced injection timing when compared to other injection timings. This is because of the lower cetane number of the LGO-diesel blends compared with the diesel fuel [31]. The ignition may occur sufficiently late in the expansion process for the burning process. For fuels with a higher 
cetane number and shorter ignition delays, ignition occurs before most of the fuel is injected. Ignition delay periods vary from $19^{\circ}$ to $21^{\circ} \mathrm{CA}$ for all blends of LGO-diesel fuels. when the fuel injection starts later, the temperature and pressure are initially high but then decrease as the delay proceeds. In Figure 4, cylinder pressure increases during the advanced injection timing compared with other injection timings for all blends of LGO-diesel fuels. The reason may be that most of the fuels burn in the premixed combustion phase, which leads to high peak cylinder pressure because of greater accumulation of fuel in the engine cylinder during the ignition delay period [3]. For pure diesel, the maximum cylinder pressure is 76.692 bar at advanced injection timing, which is higher by $15.5 \%$ and $18.71 \%$ than the normal and retarded injection timings respectively.
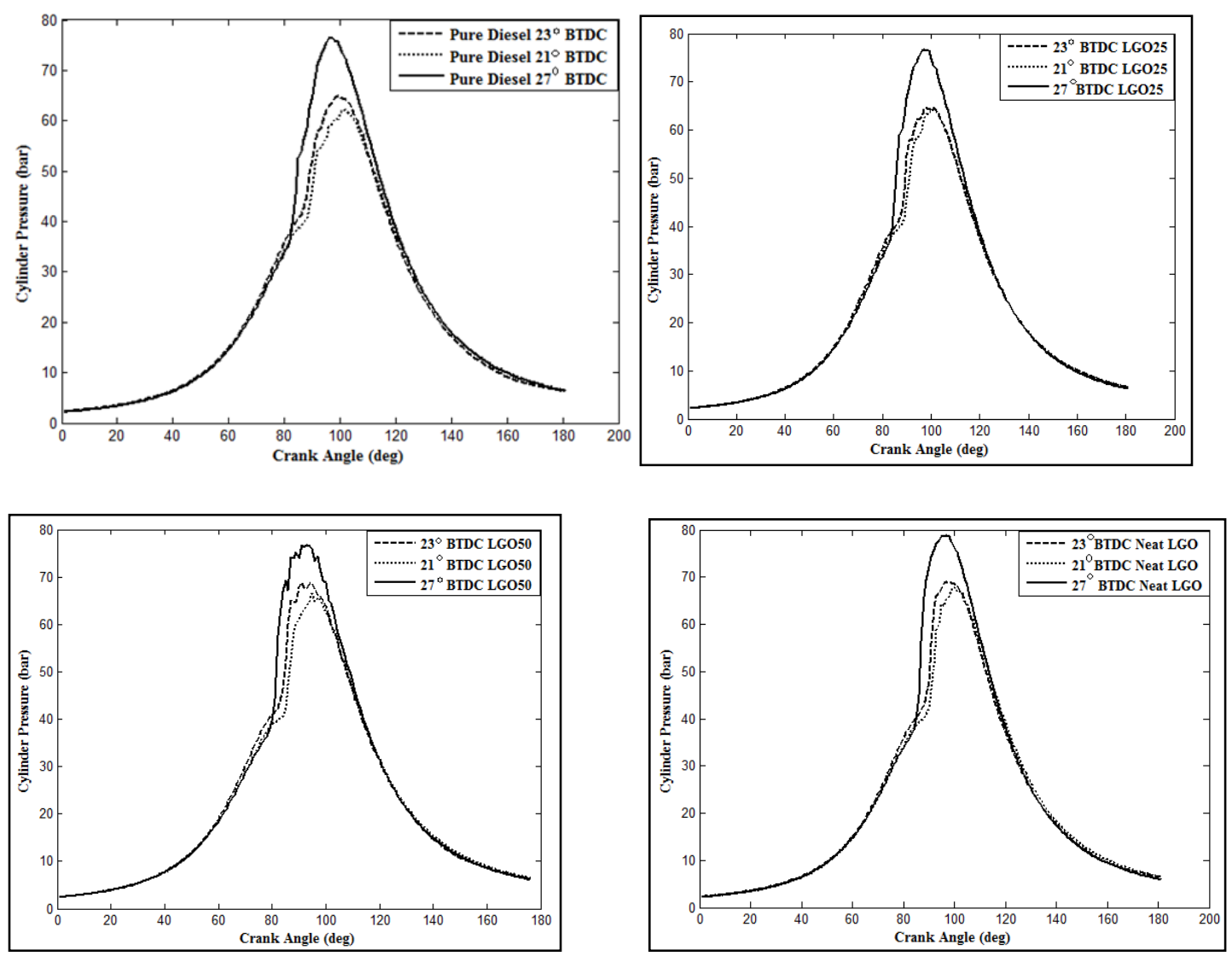

Figure 4. Variation of cylinder pressure with crank angle of LGO-diesel blends for different injection timings.

For LGO25, the cylinder pressure increases by $15.7 \%$ and $16.1 \%$ at advanced injection timing than other fuel injection timings. Moreover, it increases by $10.2 \%$ and $13.42 \%$ at advanced injection timing for LGO50 compared with retarded and normal fuel injection timings respectively. For neat lemongrass oil fuel operation, the maximum cylinder pressure is 78.808 bar at advanced injection timing, which is higher by $13.95 \%$ and $12.4 \%$ than retarded and normal injection timings respectively. The smoothness of engine operation is mostly dependent on the rate of pressure rise. The maximum rate of 
pressure rise is higher for advanced injection timing because of the higher ignition delay period (ID) which leads to higher latent heat of vaporization, higher specific heat and also higher heat of reaction [22].

\section{Heat Release Rate}

Figure 5 shows the variation of heat release rates of LGO-diesel blends with various crank angle positions for different injection timings of $21^{\circ}, 23^{\circ}$ and $27^{\circ}$ bTDC. Ignition delay is the time taken in physical and chemical reactions. Moreover, because of the evaporation of the fuel accumulated during the ignition delay period, a negative heat release can initially be observed. After combustion starts, this becomes positive. After the ignition delay, the premixed fuel-air mixture burns rapidly, followed by diffusion combustion in which the burning rate is controlled by the fuel-air mixing velocity. In Figure 5, heat release rates are higher at advanced injection timing when at other injection timings. For pure diesel, the maximum heat release rate is $92.618 \mathrm{~kJ} / \mathrm{m}^{3} \mathrm{deg}$ at advanced injection timing, which is higher by $40.48 \%$ and $26.9 \%$ than normal and retarded injection timings respectively. For LGO25, the maximum heat release rate is $109.91 \mathrm{~kJ} / \mathrm{m}^{3} \mathrm{deg}$ during the advanced injection timing, which is higher by $23.1 \%$ and 9.8\% than normal and retarded injection timings respectively.
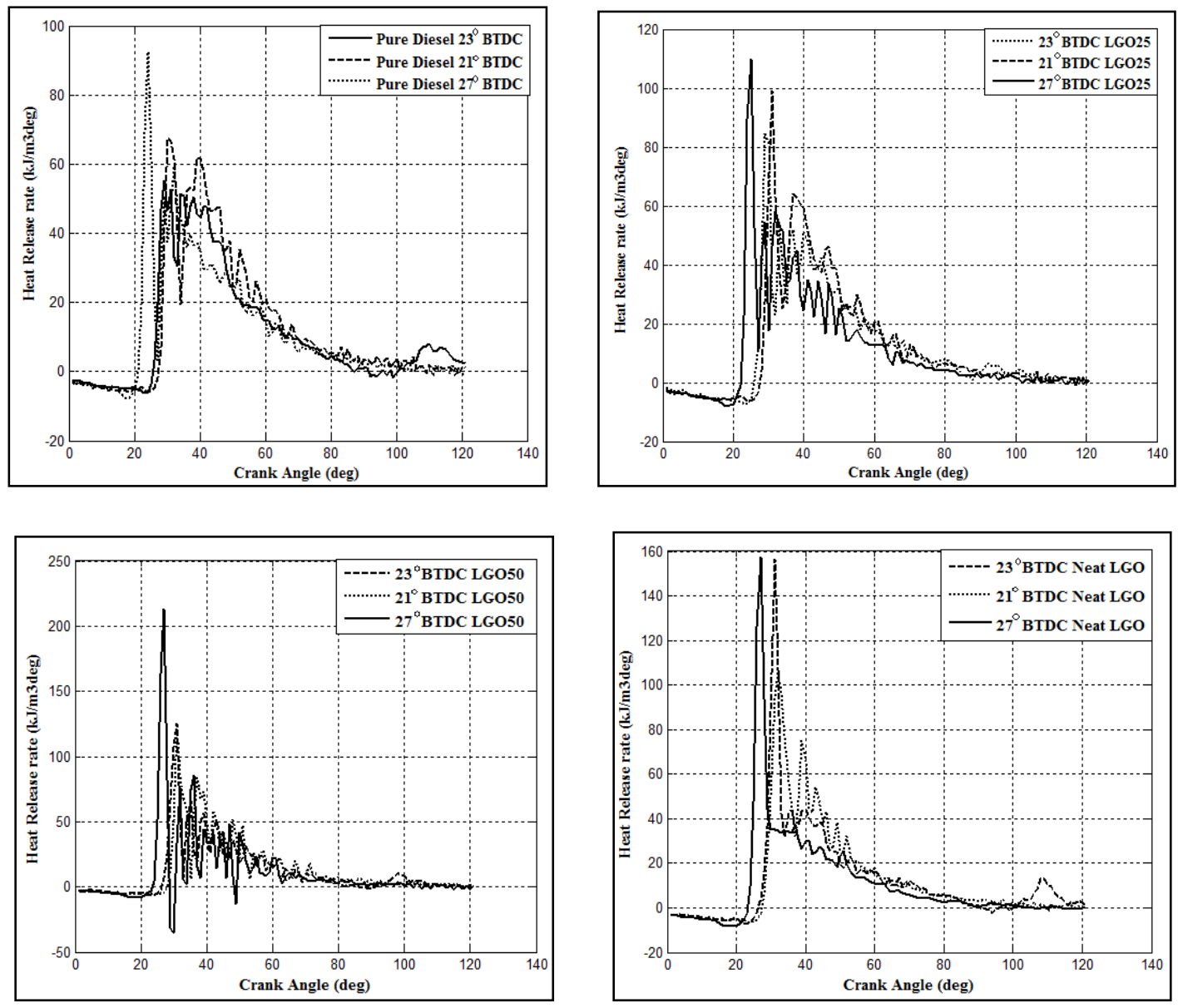

Figure 5. Variation of heat release rate with crank angle of LGO-diesel blends for different injection timings. 
For LGO50, the heat release rate at advanced injection timing increases by $41.1 \%$ and $41.7 \%$ more than normal and retarded injection timings respectivley. When neat lemongrass oil is used as fuel in the engine, the maximum heat release rate is $156.35 \mathrm{~kJ} / \mathrm{m}^{3} \mathrm{deg}, 106.07 \mathrm{~kJ} / \mathrm{m}^{3} \mathrm{deg}$ and $157.55 \mathrm{~kJ} / \mathrm{m}^{3} \mathrm{deg}$ at $23^{\circ}, 21^{\circ}$ and $27^{\circ} \mathrm{bTDC}$ fuel injection timings respectively. The reason may be that the premixed burning heat release is higher for neat LGO at advanced injection timing, which increases the air-fuel mixture in the premixed burning phase and increases fuel accumulation in the combustion chamber at the timing of the premixed burning phase, leading to a high heat release rate $[3,28]$.
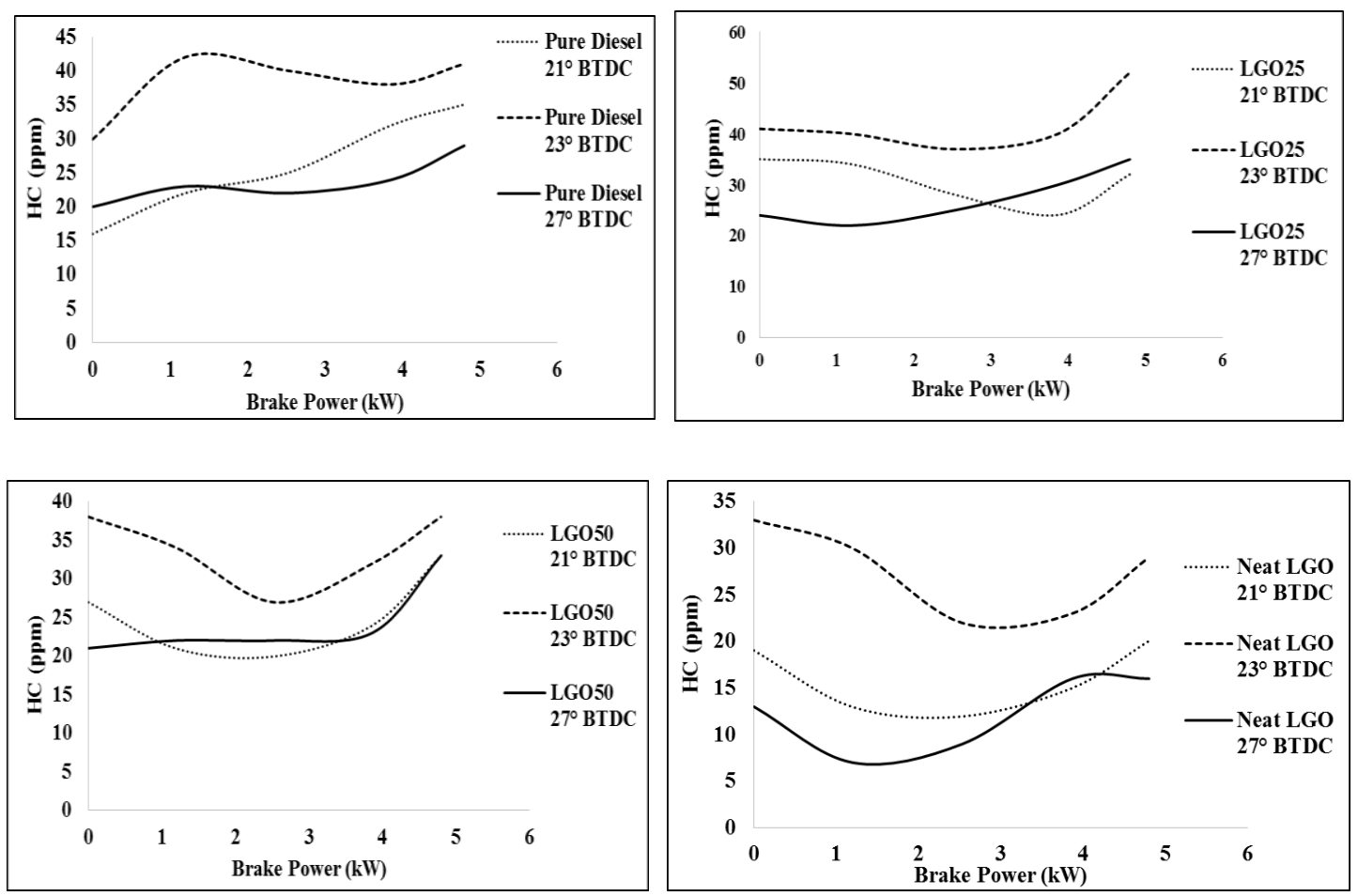

Figure 6. Variation of HC with brake power of LGO-diesel blends for different injection timings.

\section{Emission Characteristics}

The variation in $\mathrm{HC}$ emission by the engine is shown in Figure 6 for various fuel injection timings. HC emissions are formed because of incomplete combustion inside the cylinder chamber. The formation of unburned $\mathrm{HC}$ derives from various sources in the cylinder engine. $\mathrm{HC}$ emission is reduced at the advanced injection timing compared with other fuel injection timings at full load condition. For pure diesel, HC emission increases at $21^{\circ}$ by $17.1 \%$ and at $23^{\circ}$ bTDC by $29.2 \%$ more than the advanced injection timing. For LGO25, HC emission increases by $38.4 \%$ at normal injection timing. For LGO50, HC emissions show a significant increase at normal injection timing comapred with other retarded and advanced injection timings. The reason may be that the high momentum of fuel droplets produces a wider lean over-mixed region, resulting in higher 
$\mathrm{HC}$ emissions [13].For neat lemongrass oil, it is increased by $44.8 \%$ at $23^{\circ}$ and $20 \%$ at $21^{\circ}$ bTDC more than the advanced injection timing. Further, high oxygen content of neat LGO is more positive in terms of the reduction of $\mathrm{HC}$ emissions. It has been observed that higher $\mathrm{HC}$ emission at low loads is caused by the smaller quantity of fuel injected which leads to the formation of a leaner mixutre. This leaner mixture results in incomplete combustion of a significant proportion of the blend, leading to higher HC emissions $[13,32]$. Figure 7 shows the variation in $\mathrm{CO}_{2}$ emission for different injection timings of LGO-diesel blends. $\mathrm{CO}_{2}$ emission is showing an increasing trend for all the blends of LGO-diesel fuel operation. This is mainly due to the complete combustion inside the engine cylinder and also availability of oxygen in the lemongrass oil [23]. $\mathrm{CO}_{2}$ emission is increased during the advanced injection timing for all the LGO-diesel blends when compared to the normal and retarded injection timings. This is primarily due to the more complete combustion because of higher oxygen content of the LGOdiesel blends during the advanced injection timing [30].
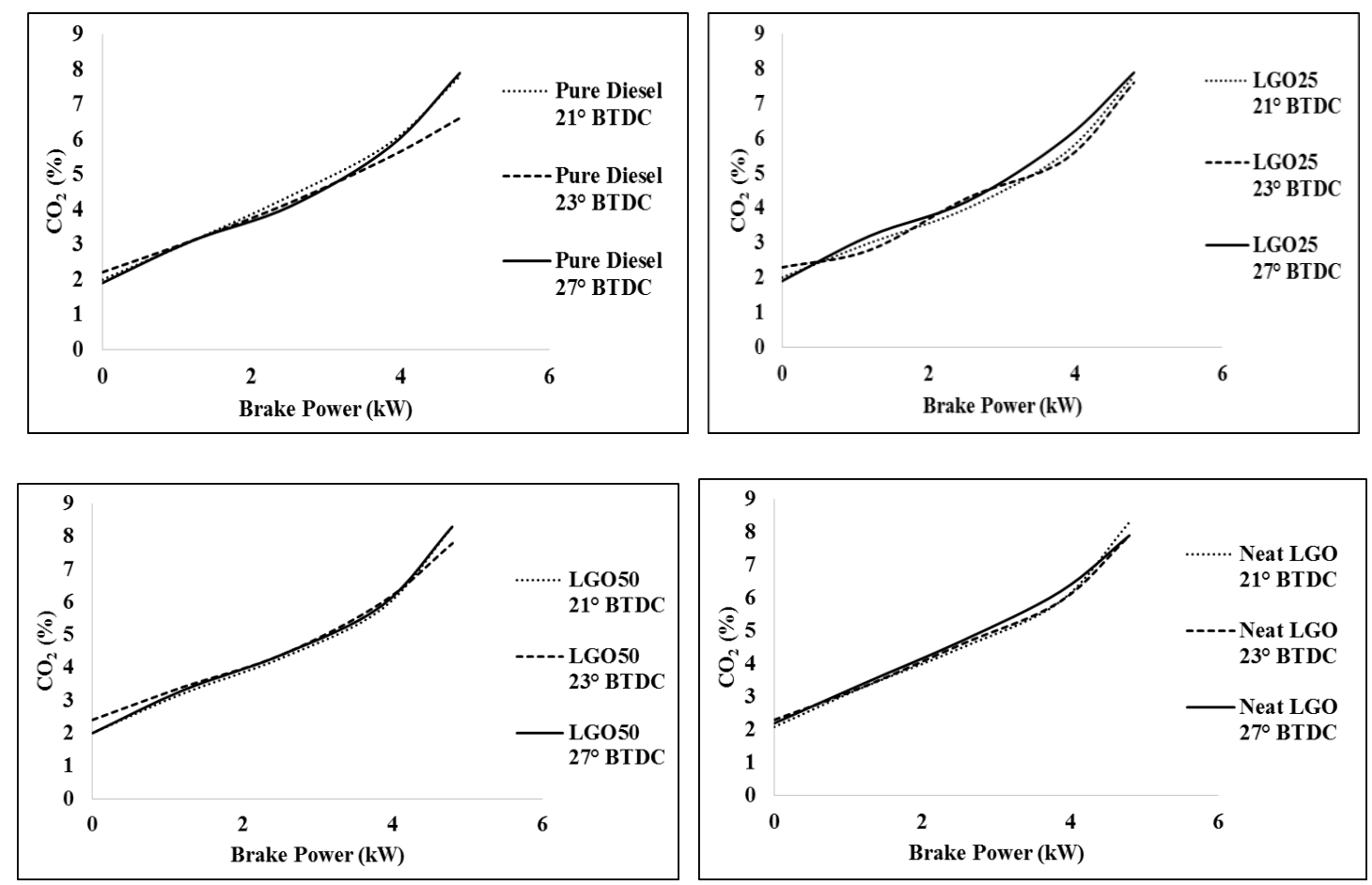

Figure 7. Variation of $\mathrm{CO}_{2}$ with brake power of LGO-diesel blends for different injection timings.

The formation of $\mathrm{NO}_{\mathrm{x}}$ emission is mainly caused by the peak cylinder temperature and the crank angle at which it occurs. Nitrogen is an inert gas and increases with the increase in engine torque. At the end of combustion, the mixture temperature inside the chamber increases, which leads to the oxidation of nitrogen with oxygen. The formation of $\mathrm{NO}_{\mathrm{x}}$ is highly dependent on the maximum temperature of the burning gases, oxygen content and residence time available for the reactions to take place in these extreme conditions [30, 33]. The oxygen content of LGO-diesel blends is an important factor in the formation of $\mathrm{NO}_{\mathrm{x}}$ because of the high local temperatures owed to excessive hydrocarbon oxidation $[3,30]$. 

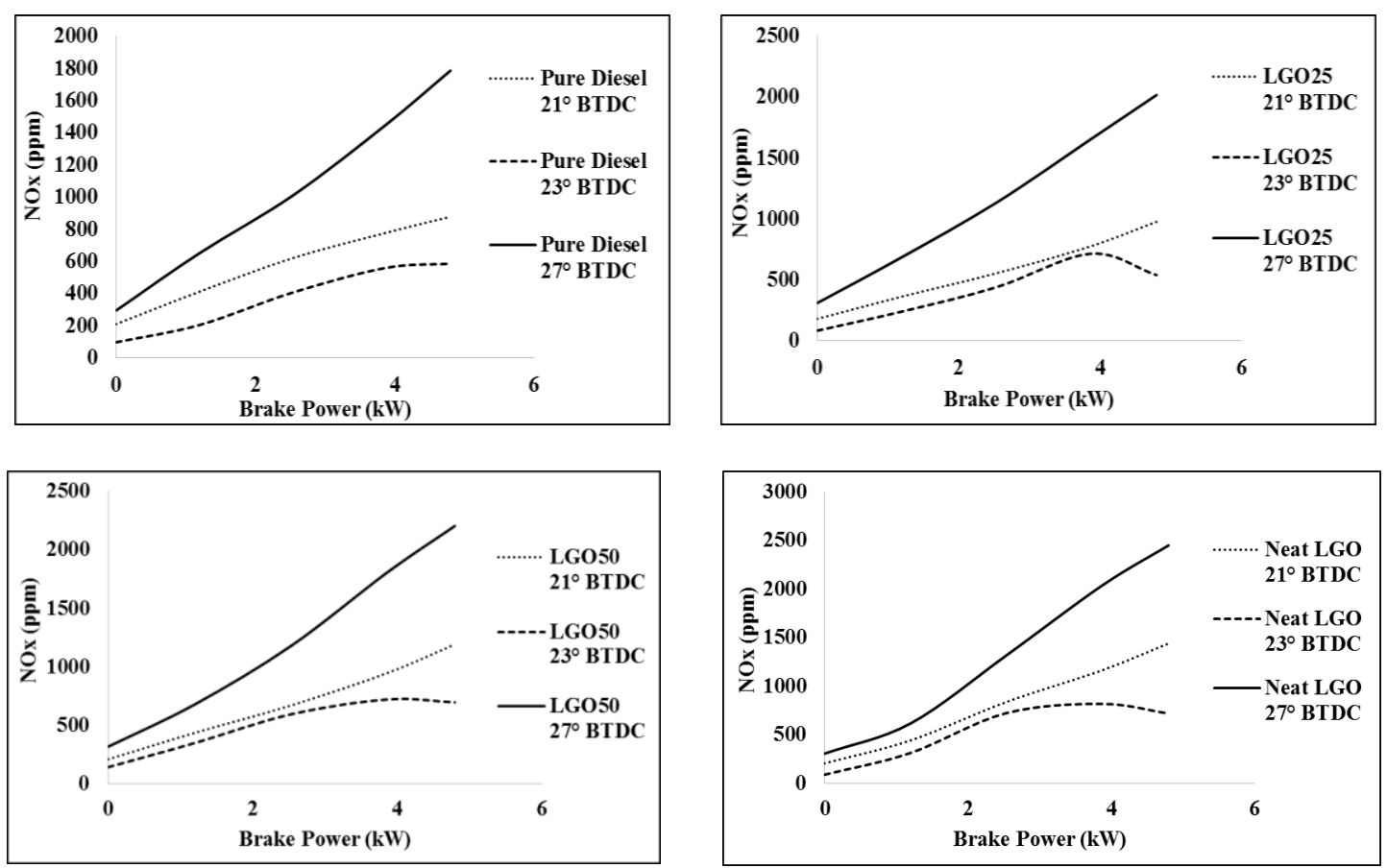

Figure 8. Variation of $\mathrm{NO}_{\mathrm{x}}$ with brake power of LGO-diesel blends for different injection timings.

The increased oxygen level increases the maximum temperature during the combustion, which in turn increases the $\mathrm{NO}_{\mathrm{x}}$ formation [13]. Figure 8 shows the variation of $\mathrm{NO}_{\mathrm{x}}$ emission with respect to different injection timings for different blends. The injection timings can be retarded to give low $\mathrm{NO}_{\mathrm{x}}$ emissions without affecting the engine power and fuel efficiency, but this usually results in an increase in soot emissions and higher BSFC. As shown in Figure 8, $\mathrm{NO}_{\mathrm{x}}$ emission is higher at advanced injection timing for all the test fuels. The maximum $\mathrm{NO}_{\mathrm{x}}$ emission is observed for neat LGO as $2449 \mathrm{ppm}$ which is $21.1 \%$ higher than that of pure diesel fuel operation at full condition. At normal injection timing, $\mathrm{NO}_{\mathrm{x}}$ emission exhibits lower values when compared with other fuel injection timings. For pure diesel, $\mathrm{NO}_{\mathrm{x}}$ emission increases by $33.1 \%$ at $21^{\circ}$ and $67.28 \%$ at $27^{\circ}$ bTDC compared with normal injection timing. For LGO25, it increases by $44.29 \%$ at $21^{\circ}$ and $73.11 \%$ at $27^{\circ}$ bTDC. For LGO50, it is increased by $41.7 \%$ at $21^{\circ}$ and $68.6 \%$ at $27^{\circ}$ bTDC. When neat lemongrass oil is used as fuel, it increases by $50.1 \%$ at $21^{\circ}$ and $70.6 \%$ at $27^{\circ}$ bTDC respectively compared with standard injection timing. The reason for the higher $\mathrm{NO}_{\mathrm{x}}$ emission is the higher peak temperature $[13,32]$. On the other hand, the higher oxygen content of neat LGO and more fuel burned in the premixed burning phase might result in high temperatures and high $\mathrm{NO}_{\mathrm{x}}$ formation during the advanced injection timing.

Smoke formation is influenced by the fuel-air equivalance ratio, fuel spray characteristics and combustion temperature during the diffusion combustion phase. Figure 9 shows the variation in smoke emission with brake power for different fuel injection timings. Smoke emission exhibits very low values during advanced injection timing at all loads. For pure diesel fuel operation, smoke emission increases by $48.3 \%$ at $21^{\circ}$ and $42.11 \%$ at $23^{\circ}$ bTDC compared with advanced injection timing. For LGO25, smoke emission increases by $57.5 \%$ at $21^{\circ}$ and $25.7 \%$ at $23^{\circ}$ bTDC. For LGO50, smoke emission increases by $64.4 \%$ at retarded injection timing and $62.8 \%$ at normal injection compared with advanced injection timing. For neat lemongrass oil operation, the diesel 
engine smoke level shows a decreasing trend at all loads of operation. Smoke emission increases by $85.1 \%$ more at $21^{\circ}$ and $86.2 \%$ more at $23^{\circ}$ bTDC positions than advanced injection timing. The smoke formation primarily occurs in the fuel-rich zone of the combustion chamber at high pressures and temperatures [13, 32]. When the fuel is partially oxygenated, local over-rich regions can be reduced and the formation of smoke can be limited to the advanced injection timing.
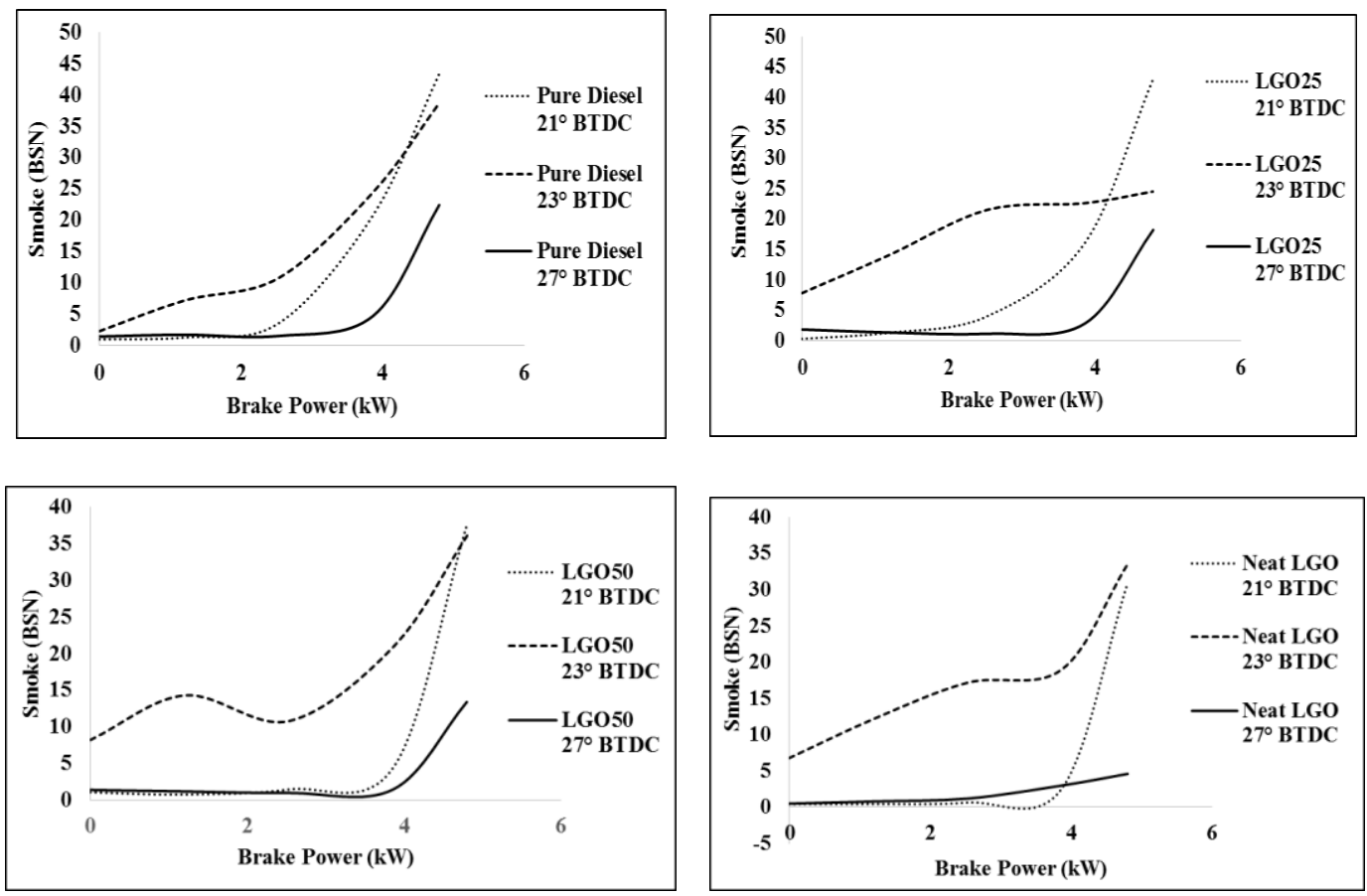

Figure 9. Variation of smoke with brake power of LGO-diesel blends for different injection timings.

\section{CONCLUSIONS}

The following results derive from the investigation carried out on the performance, combustion and emission behavior of LGO-diesel blends in a direct diesel engine for various injection timings of $21^{\circ}, 23^{\circ}$ and $27^{\circ} \mathrm{bTDC}$.

i) The advanced injection timing resulted in a significant improvement in the performance and emissions of LGO-diesel blends because of better combustion. When the injection timing is advanced, ignition delay is increased and leads to the more prominent initial phase of combustion in the premixed region.

ii) BSFC is reduced during the advanced injection timing compared with the normal and retarded injection timings for all the blends of LGO-diesel fuel.

iii) Brake thermal efficiency at advanced injection timing is significantly increased for all the blends of LGO-diesel fuels.

iv) Peak cylinder pressure and heat release rate are higher during the advanced injection timing than at normal and retarded injection timings in full load condition.

v) Emissions such as smoke and unburnt hydrocarbon were found to be lower at advanced injection timing than at the other injection timings. 
vi) $\mathrm{NO}_{\mathrm{x}}$ emission has a lower value at normal injection timing than other injection timings. At advanced injection timing, $\mathrm{NO}_{\mathrm{x}}$ emission is very high because of peak cylinder pressure and temperature during the combustion phase.

vii) However, further research on the long-term run and wear analysis of the LGOfuelled diesel engine is also necessary.

viii) On the other hand, the test results indicate that neat lemongrass oil is a potential alternative fuel for unmodified diesel engines.

\section{ACKNOWLEDGEMENTS}

The authors thank the HOD and staff members (Dept. of Mechanical) of Sri Venkateswara College of Engineering, Sriperumbudur, Chennai for their help to utilize the Internal Combustion Engine Laboratory in conducting the experiments and also the Anna University, Chennai for pursuing this research work (Research id: 2011/2011172050)

\section{REFERENCES}

[1] Salgon JJ, Robbe-Valloire F, Blouet J, Bransier J. A mechanical and geometrical approach to thermal contact resistance. International Journal of Heat and Mass Transfer. 1997;40:1121-9.

[2] Sathiyamoorthi R, Sankaranarayanan G. Experimental investigation of performance, combustion and emission characteristics of neat lemongrass oil in DI diesel engine. International Journal of Current Engineering and Technology 2014; S3:25-30.

[3] Agarwal AK, Srivastava DK, Dhar A, Maurya RK, Shukla PC, Singh AP. Effect of fuel injection timing and pressure on combustion, emissions and performance characteristics of a single cylinder diesel engine. Fuel. 2013;111:374-83.

[4] Puhan S, Vedaraman N, Sankaranarayanan G, Ram BVB. Performance and emission study of Mahua oil (madhuca indica oil) ethyl ester in a 4-stroke natural aspirated direct injection diesel engine. Renewable Energy. 2005;30:1269-78.

[5] Sankaranarayanan G, Jayaraj J, Saravanan N, Jeyachandran K. Performance and emission studies on DI diesel engine using Madhuca indica oil and hydrogen as dual fuel. Proceedings of the 19th national conference on IC engines and combustion, Annamalai University, India2005. p. 83-6.

[6] Pugazhvadivu M, Sankaranarayanan G. Experimental studies on a diesel engine using mahua oil as fuel. Indian Journal of Science and Technology. 2010;3:78892.

[7] Sathiyamoorthi R, Sankaranarayanan G. Combustion characteristics of dici engine on various injection parameters using neat lemongrass oil-diesel blends. Journal of Chemical and Pharmaceutical Sciences. 2015;1:103-8.

[8] Aziz A, Rashid A, Firmansyah, Shahzad R. Combustion analysis of a CNG direct injection spark ignition engine. International Journal of Automotive and Mechanical Engineering. 2010;2:157-70.

[9] Rostami S, Ghobadian B, Kiani Deh Kiani M. Effect of the injection timing on the performance of a diesel engine using Diesel-Biodiesel blends. International Journal of Automotive and Mechanical Engineering. 2014;10:1945-58. 
[10] Rahman MM, Kamil M, Bakar RA. Engine performance and optimum injection timing for 4-cylinder direct injection hydrogen fueled engine. Simulation Modelling Practice and Theory. 2011;19:734-51.

[11] Hamada KI, Rahman MM, Abdullah MA, Bakar RA, A. Aziz AR. Effect of mixture strength and injection timing on combustion characteristics of a direct injection hydrogen-fueled engine. International Journal of Hydrogen Energy. 2013;38:3793-801.

[12] Rahman MM, Mohammed MK, Bakar RA. Effects of air fuel ratio and injection timing on performance for four-cylinder direct injection hydrogen fueled engine. European Journal of Scientific Research. 2009;25:214-25.

[13] Pundir B. Engine emissions: pollutant formation and advances in control technology: Alpha Science International, Limited; 2007.

[14] Shundoh S, Komori M, Tsujimura K, Kobayashi S. NOx reduction from diesel combustion using pilot injection with high pressure fuel injection. SAE Technical Paper NO. 920461; 1992.

[15] Dürnholz M, Endres H, Frisse P. Preinjection a measure to optimize the emission behavior of DI-diesel engine. SAE Technical Paper No 940674; 1994.

[16] Rahman SMA, Masjuki HH, Kalam MA, Sanjid A, Abedin MJ. Assessment of emission and performance of compression ignition engine with varying injection timing. Renewable and Sustainable Energy Reviews. 2014;35:221-30.

[17] Hwang J, Qi D, Jung Y, Bae C. Effect of injection parameters on the combustion and emission characteristics in a common-rail direct injection diesel engine fueled with waste cooking oil biodiesel. Renewable Energy. 2014;63:9-17.

[18] Saravanan S, Nagarajan G, Lakshmi Narayana Rao G, Sampath S. Theoretical and experimental investigation on effect of injection timing on NOx emission of biodiesel blend. Energy. 2014;66:216-21.

[19] Liu J, Yao A, Yao C. Effects of injection timing on performance and emissions of a HD diesel engine with DMCC. Fuel. 2014;134:107-13.

[20] Wang Y, Zhao Y, Xiao F, Li D. Combustion and emission characteristics of a diesel engine with DME as port premixing fuel under different injection timing. Energy Conversion and Management. 2014;77:52-60.

[21] Ryu K. Effects of pilot injection timing on the combustion and emissions characteristics in a diesel engine using biodiesel-CNG dual fuel. Applied Energy. 2013;111:721-30.

[22] Sayin C, Ozsezen AN, Canakci M. The influence of operating parameters on the performance and emissions of a DI diesel engine using methanol-blended-diesel fuel. Fuel. 2010;89:1407-14.

[23] Jaichandar S, Senthil Kumar P, Annamalai K. Combined effect of injection timing and combustion chamber geometry on the performance of a biodiesel fueled diesel engine. Energy. 2012;47:388-94.

[24] Pomeroy CA. Science watch-biogas breakthrough. The Japan Journal. 2008.

[25] Kim HJ, Lee KS, Lee CS. A study on the reduction of exhaust emissions through HCCI combustion by using a narrow spray angle and advanced injection timing in a DME engine. Fuel Processing Technology. 2011;92:1756-63.

[26] Akbari M, Galanis N, Behzadmehr A. Comparative assessment of single and two-phase models for numerical studies of nanofluid turbulent forced convection. International Journal of Heat and Fluid Flow. 2012;37:136-46. 
[27] Buyukkaya E, Cerit M. Experimental study of NO x emissions and injection timing of a low heat rejection diesel engine. International Journal of Thermal Sciences. 2008;47:1096-106.

[28] Sayin C, Gumus M. Impact of compression ratio and injection parameters on the performance and emissions of a DI diesel engine fueled with biodiesel-blended diesel fuel. Applied Thermal Engineering. 2011;31:3182-8.

[29] Raheman H, Ghadge S. Performance of diesel engine with biodiesel at varying compression ratio and ignition timing. Fuel. 2008;87:2659-66.

[30] Sayin C, Gumus M, Canakci M. Effect of fuel injection timing on the emissions of a direct-injection (DI) diesel engine fueled with canola oil methyl esterdiesel fuel blends. Energy \& Fuels. 2010;24:2675-82.

[31] Suryawanshi JG, Deshpande N. Effect of injection timing retard on emissions and performance of a pongamia oil methyl ester fuelled CI engine. SAE Technical Paper No 2005-01-3677; 2005.

[32] Heywood JB. Internal combustion engine fundamentals: Mcgraw-hill New York; 1988.

[33] Zhang G, Qiao X, Miao X, Hong J, Zheng J. Effects of highly dispersed spray nozzle on fuel injection characteristics and emissions of heavy-duty diesel engine. Fuel. 2012;102:666-73.

\section{NOMENCLATURE}

DI Direct Injection

CI Compression ignition

BSFC Brake Specific Fuel Consumption

BTE Brake Thermal Efficiency

LGO Lemongrass oil
bTDC before Top Dead Center

$\mathrm{NO}_{\mathrm{x}}$ Oxides of nitrogen

$\mathrm{CO}_{2}$ Carbon dioxide

$\mathrm{HC}$ Hydro carbon

CA Crank Angle 